Saudi Journal of Humanities and Social Sciences

Abbreviated Key Title: Saudi J Humanities Soc Sci

ISSN 2415-6256 (Print) | ISSN 2415-6248 (Online)

Scholars Middle East Publishers, Dubai, United Arab Emirates

Journal homepage: http://scholarsmepub.com/sjhss/

Original Research Article

\title{
Effects of Teaching and Learning Resources in Lower Primary School Children in the Eastern Zone of Nakuru Municipality, Kenya
}

\author{
Samwel Njenga Njoroge ${ }^{*}$ \\ School of Education Mount Kenya University, Nakuru Campus
}

DOI: $10.36348 /$ sjhss.2019.v04i12.004

| Received: 07.12.2019 | Accepted: 19.12.2019 | Published: 22.12.2019

*Corresponding author: Njoroge Samwel Njenga

\section{Abstract}

The essence of teaching and learning materials to any learning institution cannot be overemphasised. This is more so when it comes to the learning of the young children. This research study focused on the effects of learning and teaching resources in lower primary school children. The education system in Kenya is evolving a bit slowly even as it is faced with inadequate teaching/learning resources in lower primary schools due to poor planning and corruption in the process of acquiring learning resources. A mixture of both purposive sampling and simple random sampling techniques were used in the study. The instruments that were used in data collection include questionnaires, the interview schedule and the observation schedule. The findings were that most books in school libraries are outdated and need to be upgraded to fit with the changing world of technology especially with Social Studies. Teaching and using of black boards and toys play a very important role in the teaching and learning process.

Keywords: Learning resources, instructional resources, lower primary school, textbooks, black chalkboards, cognitive development.

Copyright @ 2019: This is an open-access article distributed under the terms of the Creative Commons Attribution license which permits unrestricted use, distribution, and reproduction in any medium for non-commercial use (NonCommercial, or CC-BY-NC) provided the original author and source are credited.

\section{INTRODUCTION}

The current Kenyan system of education is in transition from the 8-4-4 system of education to 2-6-33 . The 8-4-4 system of education is where learners spend eight years in primary school, four years in secondary school and the last four years at the university. In the process of transition it is not only structure that changes but also the content keeps changing.

It is clear from studies conducted in education that learning and teaching resources have a positive effect to children's learning. Of special importance are those in primary school because of the tender and sensitive stage they are in, by virtue of their age.

These are children who more often than not, depend on what they see and touch for their cognitive development. Teaching and learning tools like charts, toys, play tend to help a child's holistic growth because they appeal to many senses hence aid in ease acquisition of knowledge. Teaching and learning resources make the classroom lively and active this includes tools like videos, illustrations and practice apparatus. This means it brings enjoyment of teaching and learning in classrooms. Therefore, the kind of learning and teaching resources teachers use solely dictates what type of people children grow up to be. Through play, children interact more with a world outside the comfort of the laps of their mothers and become exposed to a world of competition demanding concentration, discipline and diligence. Children are especially vulnerable to stress and emotional overload, making it more difficult for them to function especially in a classroom setting that does not take cognizance of the theories of learning. According to Faize and Dahan [1] as cited in Bukoye [2] teaching and learning materials are shown to include print and non-print items that are designed to impact information to students in the educational process. The teaching and learning resources include items such as prints, textbooks, magazines, newspapers, slides, pictures, workbooks, electronic media among others.

According to Amadioha [3] teaching and learning resources constitute of alternative channels of communication which a teacher can use to convey more vividly instruction to learners. They represent a wide range of materials which can be used to extend the range of vicarious experience of learners in a teachinglearning experience. 
One of the importances of teaching aids includes motivation through which, they inspire students so that they can learn better. Charts with pictures help pupils be motivated to learn more about a subject as curiosity is created.

Another important role played by teaching and learning materials is that they help in Clarification of abstract content. Through teaching aids, a teacher is able to clarify the subject matter more easily. Teaching and learning resources also help in discouragement of cramming in that they facilitate proper understanding through hands on exposure to the students which discourages the act of cramming. When a pupil is able to hold and see, then forgetting is not possible. In this way, the vocabulary of the students is also improved.

\section{Statement of the problem}

The effects of learning and teaching resources as used by teachers for lower primary school children in Eastern Zone of Nakuru Municipality are widespread and beneficial to the full-term development of a child. There are a number of schools across the Eastern Zone of Nakuru Municipality and many of these harbour children from poor backgrounds; majority of who lack learning resources as provided for from homes. Therefore, it becomes a struggle for many parents sending children to school and managing to keep them there. For those who can afford to supplement the resources however, learning for children becomes easier.

It is the researcher's contention that if there is neglect on the issue touching on teaching and learning resources in primary schools, the full potential of lower primary school children may never be discovered. In the end the ripple effects are carried over to other levels of schooling. It is on this premise that this study explored to find out the effects of teaching and learning resources in lower primary school children.

\section{LITERATURE REVIEW}

Over recent decades there has been a massive effort by developing countries to put their children to school. Educational attainment, especially primary education, is perceived as one of the main vehicles for spurring economic growth and improving living standards in developing countries.

There is a great difference in the teaching process of the young children from adults. A lot of learning in childhood entails concrete learning with minimal abstract knowledge teaching due to their lack of exposure. There are several things which need consideration in creating effective instruction in teaching. Brown [1] as cited in Sukmahidayanti [4] proposes some characteristics of practical approach in teaching young children. They include; intellectual development, attention span, sensory input, effective factors and authentic meaningful language. All these calls for the teacher to utilize the instructional media optimally in a classroom setting to enhance teaching and learning.

According to Amadioha [3] in using teaching and learning resources, teachers and learners do not only extend the range of sense organs used but also extend the range of materials used for convening the same message through the same organ. In other words, the learning resources appeal to more than one sense organ hence aiding the learners to grasp the content with much ease.

Omambe [5] as cited in Ajoke [5] asserts that instructional materials are central in the teaching and learning of English language because they are used to compliment efficiency of a teacher and effectiveness in lesson development. By extension this is true about teaching all the other subjects in lower primary school. Esu, Enukoha and Umoren [6] affirmed that teaching and learning resources facilitate learning of abstract concepts by helping to concretize ideas and stimulate learner's imagination. This is in agreement with Piaget theory of learning which stipulates use of concrete materials to teach the young children.

Oluwagbohunmi and Abdu-Raheem [7] as cited in Ajoke [5] acknowledged that teaching and learning resources are such materials used by teachers to aid explanations and make learning of subject matter understandable to students during teaching and learning process. Kochhar [8] supported that instructional materials are very significant learning and teaching tools. He suggested the need for teachers to find necessary materials for instruction to supplement what textbooks provide in order to broaden and arouse student's interests in the subject. This is true bearing in mind the fact that instructional materials appeal to more than one sense of organ.

Given the vast resources invested in education by different education stakeholders, understanding what factors and investments most efficiently improve student learning is of crucial importance. This research study was steered towards that goal in the lower primary schools of Nakuru Municipality, Eastern Zone.

In this chapter, the researcher reviewed various sources of the effects of teaching and learning resources in lower primary schools in an inclusive setting through text books, journals, the internet, magazines and the community.

The researcher focused on various areas that might be affecting lower primary school children in this area of Nakuru Municipality in terms of teaching and learning resources. The researcher identified the types of learning and teaching resources, and the impacts of the availability of these learning and teaching resources. 


\section{Types of teaching and learning resources}

The selection of teaching and learning materials is an integral part of curriculum planning and delivery in primary schools. Children and students come into contact with a vast array of print, visual and multimedia materials in their daily lives. Their exposure to such materials is mediated by parents and other caregivers, by legislation and by social conventions. Educators also have a duty of care to ensure that the teaching and learning materials with which children and students are presented, or towards which they are directed, are appropriate to their developmental growth and relevant to the achievement of appropriate learning outcomes.

The types of learning and teaching aids available can be classified into three main categories:

- Visual aids

- Audio aids

- Audio-visual aids

Visual Aids: Thungu, Wandera, Gachie \& Alumande [1] say that items under this category of visual materials appeal to the sense of sight. For example :- actual objects, models, pictures, charts, maps, flash cards, flannel board, bulletin board, chalkboard, overhead projector, slides etc. Out of these black boards are the commonest ones and are used by all teachers in the Eastern Zone of Nakuru Municipality. Charts are also common and aid a lot where children are not able to read.

Audio Aids: The Audio aids involve a sense of hearing and include the radio, tape recorder, gramophone etc.

The invention of free primary education (FPE) in Kenya saw many schools receive radios for learning and teaching purposes. However, these radios are used sparingly because of lack of time to utilise them.

Audio - Visual Aids: The Audio- Visual instructional materials appeal to the sense of sight and hearing. They are effective when teaching large number of students [1]. For example here we have: television, film projector, film strips etc. These are not usually used by teachers in the Eastern Zone of Nakuru Municipality mainly because they are expensive and are not readily available in most of these schools. However, in the new curriculum of Competency Based Curriculum, teachers sometimes give children exercises which they have to do with the parent at home using television or the mobile phones.

Lower primary school teachers and parents are responsible for ensuring that each education site has a process for selecting, teaching and learning materials and for providing access to them. This includes those materials accessible to children and students on-site (for instance through libraries and resource centres and including online resources).

From lower primary school to university, there is a nearly unlimited supply of learning resources for students. These resources come in a variety of formats, all serving a single purpose - to enhance learning outcomes for students [4]. Resources for a wide variety of subjects can be found online, unfortunately, this area is not exploited due to computer illiteracy and technophobia exhibited by majority of lower primary school teachers in the Eastern Zone. Many parents and teachers are not computer literate making this type of teaching and learning resource almost non-existent. There is however a new trend that is going to give this type of learning some impetus. The new curriculum currently in lower primary at times gives extended work where the learner has to collaborate with the parents and does research online touching on different aspects like what their community used to do in the past as an economic venture. Other types of learning resources can be found through publishers; such as, Kenya Institute of Curriculum Development (KICD.) which, through its curricular, recommends easy teaching and learning for lower primary school children. Books with pictures and colours are good learning materials for lower primary school children. There are also educational initiatives that make it necessary for children to interact through social events like play and games [9]. Play, being the most used teaching/learning resource, is something done out of fun or that which one engages in recreational purposes. It has many forms under its umbrella, including fantasy, storytelling, music, movement, games, among others. Play almost always promotes excitement, enjoyment, and a relaxing atmosphere. From this, children are able to learn through observing and imitating. The communication that occurs in play requires children to know what to communicate, how to communicate, and to understand other's communication. In a more general sense, play does not only affect the development of a child's language but it also has a remarkable effect on learning.

Children in these tender years tend to elicit a great deal of knowledge from their peers therefore how they interact with them really matters in the development of language and language skills. Through allowing lower primary school children to play therefore, a teacher creates an arena where children learn new skills and practice old ones, both physical and social. The children eventually challenge themselves to new levels of mastery. They gain competence in all areas of development-increasing language, social skills, and physical skills.

Apart from play, there are some resources which are supplemental, acting as a general complement to a specific area of study, while others are designed to be developmental, addressing the needs of struggling students. Many learning resources are 
designed to reinforce material or simply provide additional help for struggling students. There are also learning resources for students with disabilities, ranging from physical disabilities like deafness or blindness to learning disabilities such as dyslexia and autism [9].

Teachers and parents/guardians are the leading experts on learning resources. Educators spend a good deal of time with students and are in a position to directly affect what children know and learn in their formative years. Children spend almost seventy five percent of their time with teachers, so they are able to see what their teachers do and carry on with their lives and are likely to ape what they see. Teachers can actually be considered a type of learning resource in their own right.

While there are a variety of learning resources for all education levels, primary school learning resources are probably the most prevalent. This is in part because there is so much new material for early learners to be introduced to, but also because the elementary age group is so impressionable. In developed countries, a wide range of websites, social sites like Facebook and mobile applications are aimed at children and serve as learning resources in math, reading, science, and writing. Many of these products are used in classrooms across the globe; evidence that technology-based learning resources for students is in high demand. Although not yet used in any school in the Eastern Zone, the Internet serves greatly as an efficient learning and teaching resource.

\section{Research Design}

This study employed a descriptive survey design to determine factors that help in learning and teaching resources and the effects of the presence or absence of these factors. Gray [9] defines a survey as an attempt to collect data from members of a population in order to determine the current situation of that population with respect to one or more variables. He continues to say that descriptive study determines and reports the way things are and commonly involves assessing attitudes and opinion towards individuals, organizations and procedures.

\section{Target population}

Mugenda and Mugenda [10] define population as entire group of individuals' events or objects having common observable characteristics. However a target population according to Kothari [4] is the total number of respondents in the total environment of interest to the researcher. The target population of this study was the lower primary school teachers, pupils and parents in ten public primary schools of Eastern zone of Nakuru Municipality.

\section{DATA ANALYSIS METHOD}

Descriptive statistics were used to analyse data by use of excel which included the use of frequencies, charts, tables, figures and percentages because they easily communicate the research findings to majority of readers. The qualitative data was analysed and presented thematically in verbatim.

\section{RESULTS \\ Profile of lower primary school children}

Most children in lower primary school are between the ages of 5-9 years. Teaching resources are a crucial element in these children's learning. Content needs to be related in varying ways to meet the needs of the diverse students in the classroom. Content should be of high quality and be culturally relevant. Additionally, instructional and classroom management techniques that work well with some students don't necessarily work well with other poor children. The researcher looked at provision of textbooks, transport and libraries as teaching resources; and gave the following analysis.

\section{Stakeholders responsible for provision of textbooks as teaching/learning resources}

From the research done on the stakeholders responsible for textbooks provision, it was found out that the government is the major provider at $71.42 \%$, parents at $17.14 \%$, charitable organizations at $7.14 \%$ and foundations at $4.28 \%$.

It is clear from the findings that the government is the major provider of school textbooks. This is a positive finding since it is the government's responsibility to provide learning facilities to the students. It can also be observed that parents play a crucial role in supplementing the deficit. This is in relation to the cost sharing spirit. Charitable organization and foundations also aid in textbooks provision. When a learner comes to a school set up, the first resource they interact with mostly is the textbooks. The role textbooks play in third world countries cannot be overemphasised. Textbook is the nucleus to all the learning activities related to a particular curriculum [5, 2]. Therefore text books must be provided for to enhance the process of teaching and learning.

A teacher interviewed was of the opinion that:

It is the duty of the government to provide textbooks as teaching and learning resources. The initial layout where the government send money to schools and schools were to source books from the nearest bookshop in relation to the recommended books in the orange book was the best method. However, now that books are sent from Nairobi, I think the government is not doing the right thing. All schools are given the same books from the same publishers. In the free market the schools should be allowed to buy the books they feel will address their learner's basic needs since every school is peculiar in its quest to impart knowledge to the young children. 
Another teacher had contrary views and observed that: The government is doing the right thing to buy and bring books to schools because most head teachers were misusing funds meant for books. Some head teachers enriched themselves with the huge kickbacks they received from the bookshop owners.

\section{Adequacy/inadequacy of text books in schools}

Based on the research carried out, half of the respondents felt that there are insufficient textbooks in schools. Approximately one third felt that the textbooks are extremely insufficient. This is most likely due to introduction of the FPE in 2003 leading to high numbers of student enrolment. Thus the student textbooks ratio increased. $14.28 \%$ felt that the books are sufficient, with only $4.28 \%$ feeling that the books are very sufficient. $2.85 \%$ were non-committal on this subject.

Afolabi and Odeleke [7] did identify non availability, inadequacy and non-utilisation of learning materials as a result of teacher's poor knowledge as factors responsible for the use of lecture method. On the other hand it has been noted that the success of achieving what they are meant to achieve in an instructional situation depend on the suitability of instructional materials, adequacy and effective utilization of the materials $[5,8]$.

An interviewed teacher observed that:

Although the government has tried to reach the ratio of 1:1 that is one learner to one book, the rate of learner's turnover in schools is extremely high. Children transfer with books and this is very rampart in town schools. Therefore reaching the right ratio of student to book is a dream pipe.

\section{Another teacher said that:}

Much as the Kenyan government has tried to fund for text books, the books are supposed to be used only for three years then they are deemed to be obsolete. This means after every three years we go back where we were. This means attaining adequacy of books is not possible. Another challenge is changes in curriculum especially Social Studies content which keeps changing at an alarming rate making books become irrelevant every now and then.

\section{Extent to which books in schools are relevant to the changing needs of learners}

From the research findings, $30.14 \%$ of the respondents argue that the books are not relevant to the changing needs of learners. $27.57 \%$ strongly disagree that the books are relevant to the changing needs of learners. This is probably due to the ever changing education system, with very few resources available to acquire new books. Only $24.42 \%$ agree that the books are relevant and $16.85 \%$ strongly agree that the books are relevant to the changing needs of learners. This small percentage would probably reflect few schools that are well endowed with resources as a result of the well-being of the parents.

A teacher probed in interview observed that:

The government has greatly tried to streamline the relevance of books in relation to content and the need of learners in relation to the contemporary society. Since 2003, the government has been vetting books and those which are deemed relevant are put in orange book. This has helped schools acquire relevant teaching and learning resources.

\section{Level of importance of white and black chalkboards as teaching aids}

From information gathered a majority of the respondents, felt that these tools were very important teaching aids. $28.57 \%$ felt that the tools were important. This is because; visual aid is vital in meeting the learners' needs and is relevant to the achievement of appropriate learning outcomes. Nevertheless, $5.71 \%$ felt that these tools are least important as teaching aids and $1.42 \%$ was non-committal especially touching on white board.

Yusuf [4] as cited in Bukoye [2] says that among the most basic instructional materials are chalkboards. Chalkboard is the teaching aid that teachers frequently use particularly during lectures and discussions. There are different kinds such as blackboard, marker board, write board, felt board and magic board. However in Kenyan scenario, blackboard is the most commonly used chalk board.

An interviewed teacher observed that:

In most public primary schools we are still using black walls where the chalk dust is causing health challenges. The government need to help primary schools acquire white boards where felt pens are used and cleaning is easy.

Another teacher was seemed not ready to embrace changes was of the opinion that:

I have been teaching for the past thirty years and all along I have been using blackboard so the idea of white board is alien to me and people of my ilk. I think those propagating for such changes need to go slow.

\section{Frequency of learners going on excursion trips}

The research findings indicated that $42.85 \%$ occasionally engaged on excursion trips, $14.28 \%$ often did, $4.28 \%$ went to excursion trips very often. $28.57 \%$ rarely went on excursion trips while $10 \%$ did not go at all. From this data, it is clear that most schools shy off from taking students for excursion trips. This is because; the 8-4-4 syllabuses are timed and specific. Teachers are required to finish the syllabus at specified times. With this, there is not enough time for other activities outside class work. 
From the above findings, it is evident that excursions as one of the outdoor learning activities is given little importance. This undermines the fact that lower primary school children are more active in outdoor than indoor activities.

A teacher was of the opinion that:

The outdoor activities which should supplement specific study areas have been neglected especially in the former system of education. This impairs the ability of students to learn and practice new skills and they are not able to gain competence in other areas of development such as increasing language, social skills, and physical skills. There is light at the end of the tunnel with the introduction of Competency Based Curriculum (CBC) which removes focus from mean scores. This system of education will expose learners to the areas they are good at.

Another teacher on the same footing observed that:

If there is something good that the Kenya government has given to teachers it is Competency Based Curriculum (CBC). Initially we thought that field trips meant boarding vehicles to go far and wide. However with $C B C$ we have gone out of school with learners and cleaned our markets. We had improvised broom and overalls. At the end of it all learners gained a lot and learnt there is something they can give back to the society.

\section{Source of transport relied on for field work and related activities}

From the findings, $90 \%$ of schools rely on hired transport while $10 \%$ had school transport. It is very clear that most schools do not have their own transport for field work and related activities. This therefore increases the cost of organizing such activities due to high cost of hiring transport as compared to having their own transport. This could also contribute to most schools shying off from having excursion trips.

With regard to the data above, it is crystal clear that most schools rely on hired transport as opposed to having their own transport. Such a trend could most likely impact negatively to the schools development due to the high costs of hiring, thus hindering most schools from engaging in field work and related activities.

A teacher in the process of being interviewed said that: Field work is a very important tool in helping learners to have hands on experience especially in social Studies. However, the cost of hiring buses to ferry learners to areas of learning interests deter most schools from having frequent field work that calls for hiring vehicles to transport learners especially to distant places.
A teacher on being probed further on field trips said that:

Not all field trip require transport. For instance if we want to teach aspects of soil, we just need to walk a few meters from the school compound and we shall learn practically on types of soil, types of soil erosion and even agents of soil erosion. So saying that we do not go for field studies because we don't have school buses is a lame excuse. Teachers are trained to improvise and be creative thinkers. In my opinion this ability has been drained off the teachers by focusing on the passing of examinations. That is why CBC will come to help our learners to explore their environment.

\section{CONCLUSION AND RECOMMENDATIONS}

After conducting the research, the following major findings were noted in the Eastern Zone of Nakuru Municipality:-

The government of Kenya is doing a commendable work to provide schools with textbooks.

Some books in school libraries are outdated and need to be upgraded to fit in with the changing world of technology especially with Social Studies.

Teaching aids specifically black boards play a very important role in the teaching and learning process.

There is a challenge in going for field work because most schools do not have their means of transport so they depend on public service vehicles.

In relation to the findings above the government and other stakeholders in education need to work hand in hand to provide teaching and learning materials in order to attain one pupil per book ration.

There is need to encourage teachers to use improvisation so that they may be able to aid learners with materials which are readily available in their locality.

\section{REFERENCES}

1. Thungu, J., Wandera, K., Gachie, L., \& Alumande, G. (2011). Mastering PTE Education Nairobi: Oxford University Press.

2. Bukoye, O.R. (2019). Utilization of Instruction Materials as Tools for Effective Academic Performance of Students: Implication for Counselling cited in www.mdpi.com/journal/ proceedings on 21st October 2019.

3. Amadioha., S., (2009). The importance of instructional materials in our schools an overview as cited from https://www.researchgate.net/publication/32236891 $220^{\text {th }} /$ October 2019. 
4. Sukmahidayanti, T. (2015). The utilization of instructional media in teaching English to young learners. A case study of an elementary school teacher Bandung journal of English and Education, 3(2), 90-100.

5. Ajoke, A.R. (2017). The Importance of Instructional Materials in Teaching English as a Second Language. International Journal of Humanities and Social Science Invention ISSN (Online): 2319 - 7722, ISSN (Print): 2319 - 7714 Www. ijhssi, 6(9), 36-44.

6. Esu, A.E.O., Enukoha, O.I.T., \& Umoren, G.U. (2004). Curriculum Development in Nigeria for Colleges and Universities. Owerri Whyte and Whyte publishers.
7. Afolabi, S.S., \& Odeleke, J.O. (2010). Assessment of resources and instructional materials status in the teaching of Mathematics in South Western Nigeria. European journal of scientific research, 43(1), 406-410.

8. Kochhar, S.K. (2012). The teaching of Social Studies. New Delhi, India. Sterling publishers private Limited.

9. Ngaroga, J.M. (2008). Revision Education for primary Teacher Education. Nairobi: East Africa Educational publisher.

10. Mugenda, O.M., \& Mugenda, A.G. (1999). Research Methods: Qualitative and Quantitative Approaches. Nairobi: Africa centre for Technology Studies (ACTS) press. 